\title{
PERLINDUNGAN LAHAN PERTANIAN PANGAN BERKELANJUTAN GUNA MEMPERKOKOH KETAHANAN PANGAN WILAYAH (Studi di Kabupaten Bantul, Daerah Istimewa Yogyakarta)
}

\author{
Gesthi Ika Janti \\ Pemerintah Daerah DIY \\ Email : pageavenue82@yahoo.com
}

Edhi Martono

Fakultas Pertanian Universitas Gadjah Mada

Subejo

Fakultas Pertanian Universitas Gadjah Mada

\begin{abstract}
The need for non-agricultural land tended to increased. This encouraged the conversion of agricultural lands and if it was not regulated, it may threatened food resilience. The Government had established Law Number 41 Year 2009 regarding Sustainable Food Agricultural Land Protection to controled agricultural land conversion. This study aimed to identified and analyzed Sustainable Food Agricultural Land Protection policy planning, the obstacles faced and the solving strategy to realized regional food resilience in Bantul Regency.

The research method was descriptive analytical qualitative approach. Bantul regency was selected as the research location because it had high land conversions and had not implemented any regulation to followed up Law Number 41 Year 2009. Informants in this study were selected by purposive sampling technique from those who formulated the planning and implementation of Sustainable Food Agricultural Land Protection policy in Bantul Regency and also the farmers. The research variables were focused on aspects of land conversion, sustainable food agricultural land policy, and regional food resilience. Data was collected by in-depth interview, observation, documentation, and literature study.

The research result showed that Bantul Regency had not seriously prepared Sustainable Food Agricultural Land Protection policy regulation. So far, several studies had been conducted as basis of regulation formulation. The main obstacles were previous spatial planning policy, disobedience to the spatial planning regulations, budget allocation, interest groups, farmer's willingness and agricultural land availability. To strengthened regional food resilience, the Government of Bantul Regency reviewed spatial planning policy, enforced law of spatial planning regulations, supported budget allocation, set the Sustainable Food Agricultural Land Protection regulation, increased land productivity, and protected existing agricultural lands. Although generally, the condition of food resilience of Bantul Regency was in medium category, Sustainable Food Agricultural Land Protection regulation must be implemented immediately.
\end{abstract}

Keywords: Land Conversion, Sustainable Food Agricultural Land Protection Policy, Regional Food Resilience 


\begin{abstract}
ABSTRAK
Kebutuhan lahan non pertanian cenderung mengalami peningkatan. Hal ini mendorong terjadinya alih fungsi lahan pertanian dan apabila tidak dikendalikan dapat mengancam ketahanan pangan. Pemerintah telah menetapkan Undang-Undang Nomor 41 Tahun 2009 tentang Perlindungan Lahan Pertanian Pangan Berkelanjutan untuk mengendalikan alih fungsi lahan pertanian. Penelitian ini bertujuan untuk mengidentifikasi dan menganalisis perencanaan kebijakan Perlindungan Lahan Pertanian Pangan Berkelanjutan, kendala yang dihadapi serta strategi pemecahannya guna mewujudkan ketahanan pangan wilayah di Kabupaten Bantul.

Metode penelitian menggunakan pendekatan kualitatif yang bersifat deskriptif analisis. Kabupaten Bantul dipilih menjadi lokasi penelitian karena mengalami aktivitas alih fungsi lahan yang tinggi dan belum menetapkan regulasi untuk menindaklanjuti Undang-Undang Nomor 41 Tahun 2009. Informan dalam penelitian ini diambil melalui teknik purposive sampling yang merupakan penyusun perencanaan sekaligus pelaksana kebijakan Perlindungan Lahan Pertanian Pangan Berkelanjutan di Kabupaten Bantul serta petani. Variabel penelitian difokuskan pada aspek alih fungsi lahan, kebijakan perlindungan lahan pertanian pangan berkelanjutan, dan ketahanan pangan wilayah. Pengumpulan data dilakukan melalui wawancara mendalam, observasi, dokumentasi, dan studi pustaka.

Hasil penelitian menunjukkan Pemerintah Kabupaten Bantul belum serius dalam mempersiapkan regulasi kebijakan Perlindungan Lahan Pertanian Pangan Berkelanjutan. Sejauh ini telah dilakukan beberapa studi sebagai dasar penyusunan regulasi. Kendala utama terletak pada kebijakan penataan ruang yang telah disusun sebelumnya, pelanggaran hukum regulasi penataan ruang wilayah, alokasi anggaran perencanaan regulasi, interest groups, kesediaan petani dan ketersediaan lahan pertanian. Untuk memperkokoh ketahanan pangan wilayah, Pemerintah Kabupaten Bantul melakukan peninjauan kembali terhadap kebijakan penataan ruang, penegakkan hukum regulasi penataan ruang, pengalokasian anggaran, penetapan regulasi Perlindungan Lahan Pertanian Pangan Berkelanjutan, pemberian insentif, serta melakukan kegiatan optimasi lahan, sertipikat tanah petani dan sinkronisasi data lahan pertanian. Meski secara umum kondisi ketahanan pangan wilayah di Kabupaten Bantul dikategorikan sedang, regulasi Perlindungan Lahan Pertanian Pangan Berkelanjutan mendesak untuk segera ditetapkan.
\end{abstract}

Kata Kunci: Alih Fungsi Lahan, Kebijakan Perlindungan Lahan Pertanian Pangan Berkelanjutan, Ketahanan Pangan Wilayah

\section{PENGANTAR}

Lahan pertanian memiliki peran dan fungsi strategis sebagai sumber daya pokok dalam usaha pertanian berbasis lahan. Lahan merupakan sumber daya alam yang bersifat langka karena jumlahnya tidak bertambah, tetapi kebutuhan terhadap lahan selalu meningkat. Hal inilah yang mendorong pemerintah untuk menetapkan Undang-Undang Nomor 41 Tahun 2009 tentang Perlindungan Lahan Pertanian Pangan Berkelanjutan. Dalam Penjelasan Atas Undang-Undang Nomor 41 Tahun 2009 disebutkan bahwa alih fungsi lahan pertanian merupakan ancaman terhadap pencapaian ketahanan dan kedaulatan pangan.

Secara nasional, setiap tahun diperkirakan 80 ribu hektar areal pertanian hilang, berubah fungsi ke sektor lain atau setara 220 hektar setiap harinya (Anonim, 2013). Sementara itu, di Daerah Istimewa Yogyakarta (DIY) lahan pertanian seluas 200 hektar setiap tahunnya beralih fungsi menjadi permukiman. Hal ini berdampak pada menurunnya produksi tanaman pangan, khususnya padi. Berdasarkan perhitungan, setiap satu hektar lahan yang ditanami padi rata-rata mampu memproduksi 10 ton gabah per tahun. Apabila alih fungsi lahan per tahunnya mencapai 200 hektar, berarti produksi gabah yang hilang mencapai 2.000 ton, sementara target produksi setiap tahun selalu mengalami peningkatan (Anonim, 2011).

Sehubungan dengan hal tersebut dan dalam rangka mengimplementasikan UndangUndang Nomor 41 Tahun 2009, Pemerintah Provinsi DIY telah menetapkan Peraturan 
Daerah Provinsi Daerah Istimewa Yogyakarta Nomor 10 Tahun 2011 tentang Perlindungan Lahan Pertanian Pangan Berkelanjutan. Peraturan Daerah ini mengatur mengenai keluasan lahan pertanian produktif yang harus dipertahankan sebagai Lahan Pertanian Pangan Berkelanjutan seluas 35.911,59 hektar. Pembagiannya untuk lahan di Kabupaten Sleman seluas 12.377,59 hektar, Kabupaten Bantul seluas 13.000 hektar, Kabupaten Kulonprogo seluas 5.029 hektar, dan Kabupaten Gunungkidul seluas 5.505 hektar.

Alih fungsi lahan pertanian menjadi permasalahan tersendiri bagi Pemerintah Kabupaten Bantul sebagai daerah penghasil beras utama di DIY. Menurut Nurhadi (2010 : 81), berdasarkan ijin pengeringan tanah yang dilakukan sepanjang tahun 2006 di Kabupaten Bantul telah terjadi alih fungsi lahan pertanian menjadi non pertanian seluas 19,5692 hektar. Alih fungsi lahan pertanian tersebut umumnya digunakan untuk permukiman dan tempat usaha. Pada tahun 2010, data Kantor Pertanahan Kabupaten Bantul menunjukkan terjadi perubahan penggunaan lahan pertanian ke non pertanian seluas 57,2824 hektar. Dari total keluasan lahan tersebut, mayoritas dialihfungsikan untuk pembangunan perumahan seluas 17,7608 hektar dan tempat tinggal seluas 15,3589 hektar (Pemerintah Kabupaten Bantul, 2014). Alih fungsi lahan pertanian untuk pembangunan perumahan mengindikasikan adanya kepentingan pemilik kapital dan melibatkan stakeholders lain di lingkungan pemerintahan yang dianggap strategis dalam proses penerbitan ijin pembangunan perumahan tersebut. Hal ini berbeda dengan alih fungsi lahan pertanian untuk pembangunan tempat tinggal yang pada umumnya bersifat non komersial.
Menurut Rustiadi dan Reti (2008 : 61), konversi atau alih fungsi lahan adalah perubahan fungsi sebagian atau seluruh kawasan lahan dari fungsinya semula menjadi fungsi lain yang menjadi dampak negatif terhadap lingkungan dan potensi lahan. Alih fungsi lahan terjadi sebagai akibat pertumbuhan ekonomi dan pertambahan jumlah penduduk yang terus meningkat. Hal tersebut tercermin dari pertumbuhan aktivitas pemanfaatan sumber daya alam yang didorong oleh meningkatnya permintaan kebutuhan terhadap penggunaan lahan serta adanya pergeseran kontribusi sektor-sektor pembangunan primer, khususnya dari sektor pertanian dan pengolahan sumber daya ke sektor sekunder (manufaktur) dan sektor tersier (jasa). Iqbal dan Sumaryanto (2007 : 171), mengemukakan bahwa sawah merupakan lahan pertanian yang paling rentan terhadap alih fungsi lahan.

Rustiadi dkk (2011 : 114) menyatakan bahwa dalam hukum ekonomi pasar, alih fungsi lahan berlangsung dari aktivitas dengan tingkat land rent lebih rendah ke aktivitas dengan tingkat land rent lebih tinggi. Menurut Barlowe (1978: 181), nilai land rent memiliki hubungan yang erat dengan alokasi sumber daya lahan di antara berbagai kompetisi penggunaan sektor komersial dan strategis.

Bakry (2010: 1-13) mendefinisikan kebijakan publik sebagai keputusankeputusan atau pilihan-pilihan tindakan yang secara langsung mengatur pengelolaan dan pendistribusian sumber daya alam, finansial, dan manusia demi kepentingan publik. Regulasi kebijakan yang dikeluarkan oleh pemerintah pusat maupun pemerintah daerah/ kabupaten/kota berkaitan dengan perijinan maupun pengaturan perubahan pemanfaatan 
lahan, dapat mendorong terjadinya kegiatan alih fungsi lahan pertanian ke non pertanian. Karini (2013: 19) menyatakan bahwa berbagai kebijakan yang menyangkut masalah pengendalian alih fungsi lahan sawah sudah banyak dibuat, namun hingga saat ini implementasinya belum berhasil diwujudkan secara optimal.

Menurut Nasoetion, dalam Iqbal dan Sumaryanto (2007 : 171), terdapat tiga kendala mendasar yang menjadi alasan mengapa peraturan pengendalian alih fungsi lahan sulit terlaksana, yaitu kendala koordinasi kebijakan, pelaksanaan kebijakan, dan konsistensi perencanaan. Perencanaan berperan sangat penting dalam pengaturan pemanfaatan lahan mengingat kebutuhan akan lahan non pertanian semakin meningkat dan mengancam keberlanjutan lahan pertanian, khususnya sawah. Terkait hal ini, Wheelan (2011:217) menyatakan bahwa one key challenge for any society is allocating scarce resources.

Undang-Undang Nomor 41 Tahun 2009 tentang Perlindungan Lahan Pertanian Pangan Berkelanjutan mendefinisikan ketahanan pangan sebagai kondisi terpenuhinya pangan bagi rumah tangga yang tercermin dari tersedianya pangan yang cukup, baik jumlah maupun mutunya, aman, merata, dan terjangkau. Hanani dalam Karini (2013 : 21) menyatakan terdapat tiga aspek utama ketahanan pangan, yaitu aspek ketersediaan, akses pangan, dan penyerapan pangan.

Tulisan ini berusaha mengkaji kebijakan Pemerintah Kabupaten Bantul dalam rangka penyusunan regulasi dan implementasi Perlindungan Lahan Pertanian Pangan Berkelanjutan sebagaimana amanat UndangUndang Nomor 41 Tahun 2009 dan Peraturan Daerah Provinsi DIY Nomor 10 Tahun
2011. Secara spesifik rumusan permasalahan mencakup: (1). Bagaimana perencanaan kebijakan Perlindungan Lahan Pertanian Pangan Berkelanjutan di Kabupaten Bantul. (2). Kendala apa yang dihadapi dalam rangka perencanaan dan Perlindungan Lahan Pertanian Pangan Berkelanjutan di Kabupaten Bantul. (3). Bagaimana strategi yang dilakukan untuk mewujudkan Perlindungan Lahan Pertanian Pangan Berkelanjutan guna memperkokoh ketahanan pangan wilayah di Kabupaten Bantul. Metode penelitian menggunakan pendekatan kualitatif yang bersifat deskriptif analisis. Kabupaten Bantul dipilih menjadi lokasi penelitian karena mengalami aktivitas alih fungsi lahan yang tinggi dan belum menetapkan regulasi Perlindungan Lahan Pertanian Pangan Berkelanjutan.

\section{PEMBAHASAN}

\section{Perencanaan Kebijakan Perlindungan Lahan Pertanian Pangan Berkelanjutan Kabupaten Bantul}

Pemerintah Kabupaten Bantul belum dapat menetapkan regulasi Perlindungan Lahan Pertanian Pangan Berkelanjutan. Perencanaan regulasi baru sebatas penyusunan berbagai studi yang diperlukan guna perumusan Naskah Akademis, yaitu Pemetaan Kesuburan Lahan, Neraca Sumber Daya Alam, dan Kajian Lingkungan Hidup Strategis. Dasar pertimbangan penyusunan regulasi ini ialah Undang-Undang Nomor 41 Tahun 2009, Perda Provinsi DIY Nomor 10 Tahun 2011, dan aktivitas alih fungsi lahan pertanian menjadi non pertanian di Kabupaten Bantul yang semakin masif, khususnya di Kecamatan Banguntapan, Kecamatan Sewon, dan Kecamatan Kasihan.

Faktor-faktor yang mendorong terjadinya alih fungsi lahan pertanian di Kabupaten Bantul 
sebagai berikut: (1). Peningkatan pertumbuhan penduduk. (2). Peningkatan kebutuhan lahan non pertanian, seperti sektor industri, perdagangan, dan jasa. (3). Fenomena sawah 'kejepit', yaitu keluasan lahan kecil dan tidak memiliki akses. (4). Desakan kebutuhan hidup dan secara ekonomi nilai land rent lahan bila digunakan untuk sektor non pertanian lebih tinggi. (5). Tingginya fragmentasi lahan akibat hukum waris. (6) Secara fisik dipengaruhi tipe tanah, klasifikasi kelas lereng, jaringan irigasi, dan jarak terhadap permukiman atau peruntukan lain. (7). Kemarau panjang dan degradasi lingkungan akibat penggunaan pupuk/pestisida berlebihan serta pencemaran air irigasi. dan (8). Alokasi anggaran sektor pertanian kecil karena prioritas pembangunan diutamakan pada sektor non pertanian. Tingginya aktivitas alih fungsi lahan ini dapat dilihat dari peningkatan jumlah permohonan Ijin Perubahan Penggunaan Tanah (IPPT), Ijin Pemberitahuan/Klarifikasi Rencana Perolehan dan atau Penggunaan Tanah (Ijin Klarifikasi), dan Ijin Lokasi yang diajukan ke Kantor Pertanahan Kabupaten Bantul sebagaimana tercantum tabel 1.

Guna mempersiapkan sebaran Lahan Pertanian Pangan Berkelanjutan, Pemerintah Kabupaten Bantul telah melakukan identifikasi dan analisis potensi Lahan Pertanian Pangan

Tabel 1

Permohonan IPPT, Ijin Klarifikasi, dan Ijin Lokasi di Kabupaten Bantul Tahun 2012-2014

\begin{tabular}{lrrrrrr}
\hline \multirow{2}{*}{ Jenis permohonan } & \multicolumn{2}{c}{ Tahun 2012} & \multicolumn{2}{c}{ Tahun 2013 } & \multicolumn{2}{c}{ Tahun 2014 } \\
\cline { 2 - 7 } & \multicolumn{1}{c}{ Bidang } & Luas $\left.\mathbf{( m}^{\mathbf{2}}\right)$ & Bidang & Luas $\left(\mathbf{m}^{\mathbf{2}}\right)$ & Bidang & \multicolumn{1}{c}{ Luas $\left(\mathbf{m}^{\mathbf{2}}\right)$} \\
\hline IPPT & 158 & 51.681 & 248 & 91.021 & 310 & 93.923 \\
Ijin Klarifikasi & 253 & 314.484 & 225 & 280.842 & 249 & 284.376 \\
Ijin Lokasi & 10 & 142.465 & 3 & 53.209 & 6 & 81.946 \\
\hline Jumlah & $\mathbf{4 1 1}$ & $\mathbf{5 0 8 . 6 3 0}$ & $\mathbf{4 7 6}$ & $\mathbf{4 2 5 . 0 7 2}$ & $\mathbf{5 6 5}$ & $\mathbf{4 6 0 . 2 4 5}$ \\
\hline
\end{tabular}

Sumber : Kantor Pertanahan Kabupaten Bantul, 2014

Tabel 2

Skenario Pemanfaatan Lahan Pertanian Pangan Berkelanjutan

\begin{tabular}{|c|c|c|c|}
\hline Skenario & Lahan Inti & Lahan Penyangga & Luas \\
\hline Skenario 1 & $\begin{array}{l}\text { Sawah irigasi yang masuk kawasan } \\
\text { dengan peruntukan pertanian lahan } \\
\text { basah irigasi }\end{array}$ & $\begin{array}{l}\text { Sawah irigasi yang masuk kawasan dengan } \\
\text { peruntukan pertanian lahan kering dan lahan } \\
\text { pertanian non irigasi }\end{array}$ & $\begin{array}{l}\text { 10.905,98 Hektar terdiri } \\
\text { dari : } \\
\text { 8.803,52 Hektar Lahan Inti } \\
\text { dan 2.102,43 Hektar Lahan } \\
\text { Penyangga }\end{array}$ \\
\hline Skenario 2 & $\begin{array}{l}\text { Sawah irigasi yang masuk kawasan } \\
\text { dengan peruntukan lahan basah } \\
\text { irigasi, lahan pertanian non irigasi } \\
\text { dan peruntukan lain }\end{array}$ & $\begin{array}{l}\text { Sawah irigasi yang masuk kawasan dengan } \\
\text { peruntukan lain, terdiri dari kawasan } \\
\text { pariwisata sepanjang pantai mulai dari } \\
\text { Kecamatan Srandakan hingga Kecamatan } \\
\text { Kretek dan kawasan perdagangan-jasa yang } \\
\text { berada pada koridor Kota Bantul. }\end{array}$ & $\begin{array}{l}\text { 14.858,69 Hektar terdiri } \\
\text { dari : } \\
\text { 13.860,46 Hektar Lahan Inti } \\
\text { dan 998,23 Hektar Lahan } \\
\text { Penyangga }\end{array}$ \\
\hline Skenario 3 & $\begin{array}{l}\text { Sawah irigasi yang masuk kawasan } \\
\text { dengan peruntukan pertanian lahan } \\
\text { basah irigasi, lahan pertanian } \\
\text { non irigasi dan peruntukan lain } \\
\text { (seluruh peruntukan yang ada pada } \\
\text { Kecamatan Banguntapan, Sewon } \\
\text { dan Kasihan) }\end{array}$ & $\begin{array}{l}\text { Sawah irigasi yang masuk kawasan lahan } \\
\text { sawah dengan peruntukan pertanian lahan } \\
\text { kering dan peruntukan lain, terdiri dari } \\
\text { Kecamatan Imogiri, Dlingo, Pajangan, } \\
\text { Pandak, Piyungan, dan Pleret. }\end{array}$ & $\begin{array}{l}\text { 15.159,47 Hektar terdiri } \\
\text { dari : } \\
\text { 13.860,46 Hektar sebagai } \\
\text { Lahan Inti dan } 1.299,01 \\
\text { Hektar sebagai Lahan } \\
\text { Penyangga. }\end{array}$ \\
\hline
\end{tabular}

Sumber : Bappeda Kabupaten Bantul, 2014 
Berkelanjutan dan pemetaan lahan. Output dari kegiatan perencanaan kebijakan ini berupa Skenario Pemanfaatan Lahan Pertanian Pangan Berkelanjutan. Dalam tabel 2 disebutkan 3 skenario Pemanfaatan Lahan Pertanian Pangan Berkelanjutan yang dapat dipertimbangkan untuk diimplementasikan di Kabupaten Bantul. Kriteria lahan pertanian yang akan ditetapkan sebagai Lahan Pertanian Pangan Berkelanjutan, yaitu kesesuaian dengan Rencana Tata Ruang Wilayah (RTRW); jarak terhadap jalan, sungai dan saluran irigasi; jarak terhadap permukiman dan penggunaan lahan lain; luas hamparan lahan sawah; dan lahan pertanian yang telah disertipikatkan sebagai Sertipikat Tanah petani (lahan abadi).

\section{Kendala Perencanaan dan Perlindungan Lahan Pertanian Pangan Berkelanjutan Kabupaten Bantul}

Lambatnya penyusunan Perda Perlindungan Lahan Pertanian Pangan Berkelanjutan disebabkan beberapa aspek, yaitu:

Pertama, kebijakan penataan ruang wilayah yang belum cukup mengakomodir pembangunan sektor pertanian. Kebijakan penataan ruang wilayah di Kabupaten Bantul tertuang dalam Peraturan Daerah Kabupaten Bantul Nomor 4 Tahun 2011 tentang Rencana Tata Ruang Wilayah (RTRW) Kabupaten Bantul Tahun 2010-2030. Selanjutnya, Perda RTRW tersebut perlu untuk didetailkan sesuai dengan ketentuan yang diatur dalam Peraturan Pemerintah Nomor 15 Tahun 2010 tentang Penyelenggaraan Penataan Ruang. Pada Pasal 59 diatur bahwa setiap RTRW kabupaten/ kota harus menetapkan bagian dari wilayah kabupaten/kota yang perlu disusun Rencana Detail Tata Ruangnya (RDTR). Bagian dari wilayah yang akan disusun RDTR tersebut merupakan kawasan perkotaan atau kawasan strategis kabupaten/kota. Rencana, aturan, ketentuan dan mekanisme penyusunan RDTR Kabupaten harus merujuk pada pranata rencana yang lebih tinggi, baik pada lingkup kawasan maupun daerah.

Kebijakan penataan ruang wilayah di Kabupaten Bantul belum cukup mengakomodir sektor pertanian. Hal ini diindikasikan dari belum ditetapkannya RDTR (Rencana Detail Tata Ruang) Kecamatan bagi beberapa kawasan strategis kabupaten dan penetapan Kawasan Perkotaan Yogyakarta (KPY) pada Kecamatan Banguntapan, Kecamatan Sewon, dan Kecamatan Kasihan. Dampaknya terlihat pada peruntukan kawasan tersebut seluruhnya bagi pengembangan perumahan/permukiman. Tentu saja peruntukan ini semata-mata hanya mengedepankan aspek aglomerasi perkotaan Yogyakarta tanpa mempertimbangkan kondisi eksisting lahan pertaniannya. Kawasan Perkotaan Yogyakarta merupakan kawasan yang berfungsi sebagai wilayah yang kegiatan utamanya bukan sektor pertanian, melainkan pengembangan permukiman perkotaan, pemusatan, dan distribusi pelayanan jasa pemerintahan, pelayanan sosial dan kegiatan ekonomi. Dengan demikian, kawasan ini mempunyai peran yang strategis bagi pertumbuhan kawasan di sekitarnya.

Berdasarkan pemetaan kesuburan lahan, wilayah kecamatan yang termasuk dalam Kawasan Perkotaan Yogyakarta merupakan wilayah dengan tingkat kesuburan lahan yang tinggi dan memiliki jaringan irigasi teknis yang baik. Dengan demikian, secara signifikan akan mempengaruhi tingkat produktivitas tanaman pangan di tiga kecamatan tersebut pada khususnya, serta Kabupaten Bantul 
pada umumnya. Meskipun produktivitas tidak selalu bergantung pada keluasan lahan, namun tidak dapat dipungkiri bahwa penyusutan lahan berpengaruh pada hasil produksi tanaman pangan secara keseluruhan. Beberapa faktor yang mempengaruhi hasil produksi tanaman pangan, yaitu tingkat kesuburan lahan, keluasan lahan, pengelolaan lahan serta iklim.

Dampak kesepakatan pengembangan Kawasan Perkotaan Yogyakarta cukup berpengaruh bagi penetapan Lahan Pertanian Pangan Berkelanjutan. Pada peta RDTR ketiga kecamatan tersebut diperuntukan bagi pembangunan perumahan dan permukiman (blok kuning), sehingga sulit untuk ditetapkan sebagai Lahan Pertanian Pangan Berkelanjutan. Muncul kekhawatiran jika kecamatan yang termasuk dalam pengembangan Kawasan Perkotaan Yogyakarta ini ditetapkan sebagai Lahan Pertanian Pangan Berkelanjutan, justru akan menghambat program pembangunan pada kawasan tersebut sekaligus menghambat implementasi kebijakan Perlindungan Lahan Pertanian Pangan Berkelanjutan. Pasalnya, ketika suatu areal lahan pertanian telah ditetapkan sebagai Lahan Pertanian Pangan Berkelanjutan, maka lahan tersebut tidak dapat dialihkan peruntukannya di luar sektor pertanian pangan. Apabila terjadi alih fungsi terhadap Lahan Pertanian Pangan Berkelanjutan, maka akan dikenakan sanksi sebagaimana ketentuan yang berlaku dalam Perda Provinsi DIY Nomor 10 Tahun 2011 yang akan menjadi acuan bagi penyusunan Perda Perlindungan Lahan Pertanian Pangan Berkelanjutan di seluruh kabupaten di wilayah DIY.

Penetapan Kawasan Perkotaan Yogyakarta mengakibatkan Kabupaten Bantul mengalami kekurangan lahan untuk ditetapkan sebagai Lahan Pertanian Pangan Berkelanjutan. Luasan eksisting lahan pertanian KPY tersebut \pm 3.600 hektar, sedangkan Lahan Pertanian Pangan Berkelanjutan yang harus ditetapkan seluas 13.000 hektar dari total keluasan lahan pertanian di Kabupaten Bantul \pm 15.000 hektar. Artinya, Kabupaten Bantul mengalami kekurangan lahan pertanian seluas \pm 1.600 hektar, belum termasuk luas lahan cadangan/ penyangga yang juga harus dialokasikan apabila terjadi alih fungsi terhadap Lahan Pertanian Pangan Berkelanjutan akibat bencana alam ataupun pengadaan tanah bagi pembangunan untuk kepentingan umum. Oleh karena itu, harus dilakukan review terhadap RTRW dan RDTR Kecamatan untuk mengubah peruntukan kawasan tersebut dari seluruhnya blok kuning menjadi blok hijau pada lahan-lahan pertanian yang masih dapat dipertahankan keberadaannya.

Kedua, pelanggaran regulasi penataan ruang wilayah. Penegakkan hukum terhadap pelanggaran Peraturan Daerah Kabupaten Bantul Nomor 4 Tahun 2011 tentang Rencana Tata Ruang Wilayah Kabupaten Bantul Tahun 2010 - 2030 tidak berjalan sama sekali, bahkan fungsi pengawasan terhadap implementasinya sangat minim. Review terhadap regulasi penataan ruang wilayah digunakan untuk mengubah peruntukan suatu kawasan yang semula digunakan sebagai kawasan budidaya pertanian menjadi peruntukan lain. Muncul stigma bahwa review regulasi penataan ruang wilayah disusun untuk mensinkronkan pelanggaran eksisting penggunaan lahan dengan pengaturan peruntukan. Dalam hal ini bukan pemanfaatan yang mengacu pada peraturan yang berlaku, melainkan peraturan itu menyesuaikan dengan kondisi eksisting pelanggaran pemanfaatan 
lahan. Dengan kata lain review dilakukan guna menghapuskan pelanggaran tata ruang yang telah terjadi sebelumnya dengan cara mengubah peruntukannya.

Stigma terhadap proses review terjadi akibat adanya kepentingan-kepentingan tertentu yang berupaya memperoleh keuntungan seluas-luasnya melalui manipulasi terhadap peraturan penataan ruang. Bahkan, dalam proses review yang dilakukan secara berkala dalam jangka waktu 5 tahun, konflik kepentingan masih saja terjadi. Sebagai contoh, dalam pengajuan ijin prinsip ataupun ijin lokasi untuk mengalihfungsikan lahan pertanian menjadi perumahan.

Pemerintah Kabupaten Bantul telah menyusun regulasi untuk mengatur perkembangan perumahan di Kabupaten Bantul melalui Perda Nomor 05 Tahun 2011 tentang Bangunan Gedung dan Peraturan Bupati Bantul Nomor 36 Tahun 2011 tentang Pedoman Pembangunan Perumahan. Sebuah perumahan dapat dikatakan legal apabila memiliki Ijin Mendirikan Bangunan (IMB). Untuk mendapatkan IMB tersebut, pengembang mengajukan permohonan ijin dengan persyaratan administrasi yang harus dipenuhi meliputi: (1). Persetujuan prinsip, (2). Kesesuaian aspek tata ruang, (3). Ijin klarifikasi/ijin lokasi, (4). Pengesahan site plan, (5). Dokumen pengelolaan lingkungan, (6). Ijin Mendirikan Bangunan IMB.

Dalam keseluruhan rangkaian prosedur tersebut penyimpangan seringkali tidak dapat dihindarkan, baik dari proses pengajuan ijin prinsip maupun proses selanjutnya. Penyimpangan terhadap aspek tata ruang yang biasanya mendominasi, sementara aspek penegakkan hukum regulasi penataan ruang yang berjalan selama ini belum cukup tegas dalam menindaklanjuti setiap pelanggaran yang ada.

Ketiga, keterbatasan alokasi anggaran. Minimnya alokasi anggaran bagi perencanaan regulasi Perlindungan Lahan Pertanian Pangan Berkelanjutan merefleksikan komitmen kepala daerah sebagai pengambil kebijakan utama yang belum menunjukkan konsistensi melalui berlarut-larutnya upaya penganggaran bagi penyusunan kebijakan Perlindungan Lahan Pertanian Pangan Berkelanjutan. Meskipun demikian, belum ada kontribusi yang diberikan oleh Pemerintah Daerah DIY karena porsi alokasi anggaran sektor pertanian Kabupaten Bantul dinilai masih terlalu kecil. Lebih dari 60 persen APBD Kabupaten Bantul dialokasikan untuk belanja pegawai.

Keempat, keberadaan interest groups. Penyusunan regulasi penataan ruang dan Perlindungan Lahan Pertanian Pangan Berkelanjutan diyakini penuh dengan konflik kepentingan. Pihak-pihak yang berkepentingan ini didominasi oleh pemegang kekuasaan maupun pemilik modal yang ingin berinvestasi di wilayah Kabupaten Bantul dimana dalam upaya pengakomodasian kepentingannya mengorbankan eksistensi lahan pertanian pangan. Pengembang merupakan salah satu pihak yang memiliki kepentingan terhadap lahan pertanian dimana terdapat upaya alih fungsi lahan pertanian dalam skala besar untuk digunakan sebagai perumahan. Di satu sisi, pengembang mengambil lahan pertanian untuk dijadikan perumahan karena lokasi lahan yang cukup strategis dan memiliki lahan pertanian adalah kemudahan akses terhadap berbagai fasilitas, seperti jalan, transportasi, listrik, air bersih, dan lain-lain. Di sisi lain, petani pemilik lahan menganggap nilai keuntungan yang diterima dari sektor 
pertanian tidak sebesar jika lahan tersebut dijual kepada pengembang ataupun digunakan untuk sektor perdagangan dan jasa.

Tidak adanya dukungan dan komitmen dari kepala daerah maupun pejabat birokrasi mengakibatkan implementasi regulasi penataan ruang wilayah dilihat berdasarkan sektor yang paling menguntungkan. Tentunya hal ini sangat berpengaruh terhadap kebijakan Perlindungan Lahan Pertanian Pangan Berkelanjutan. Mekanisme kontrol tidak dapat berjalan dengan efektif karena rendahnya komitmen pengambil kebijakan.

Lemahnya komitmen pimpinan dinilai menguntungkan pemilik modal saja dan mengorbankan kepentingan pembangunan sektor pertanian. Pada akhirnya, terjadi monopoli pengambilan keputusan berdasarkan kekuasaan sehingga kabupaten seolah berkembang menjadi kerajaan kecil. Idealnya, jika memang komitmen itu ada, maka Bupati dapat mengambil jalan tengah untuk menetapkan Kawasan Perlindungan Lahan Pertanian Pangan Berkelanjutan guna mengisi kekosongan hukum pada masa transisi selama penyusunan Perda Perlindungan Lahan Pertanian Pangan Berkelanjutan belum dapat diselesaikan. Penetapan Kawasan Lahan Pertanian Pangan Berkelanjutan tersebut cukup ditetapkan melalui Peraturan Bupati. Setelah inventarisasi pemilik lahan secara by name by address selesai dilakukan dan siap untuk ditetapkan sebagai sebaran Lahan Pertanian Pangan Berkelanjutan, maka Peraturan Bupati tersebut segera dicabut dan pengaturan selanjutnya melalui Perda.

Kelima, kesediaan petani untuk ditetapkan sebagai Lahan Pertanian Pangan Berkelanjutan. Dasar pertimbangan yang mendorong pengaturan mengenai kesediaan petani ini adalah adanya pengakuan bahwa tanah merupakan hak asasi masyarakat yang memiliki lahan. Untuk menetapkan sebaran Lahan Pertanian Pangan Berkelanjutan dengan berdasar pada kesediaan petani melalui penandatanganan kesepakatan bersama dirasa cukup sulit dilakukan. Hal ini diakibatkan tingkat fragmentasi lahan yang terjadi melalui sistem waris cukup tinggi, sehingga menyulitkan instansi teknis yang bertugas melakukan pendataan. Selain itu, insentif yang rencananya akan diberikan kepada petani pemilik lahan dipandang kurang menarik.

Meskipun demikian, masih terdapat optimisme atas kesediaan petani pemilik lahan untuk ditetapkan sebagai Lahan Pertanian Pangan Berkelanjutan yang berasal dari masyarakat petani yang menggantungkan pendapatan dari pengelolaan lahan pertanian. Mereka menyatakan kesediaannya untuk ditetapkan sebagai Lahan Pertanian Pangan Berkelanjutan, namun dalam kondisi tertentu tidak tertutup kemungkinan terjadinya alih fungsi terhadap sebagian lahan mereka untuk membangun tempat tinggal. Secara ringkas pendapat para petani pemilik lahan atas kesediaannya untuk ditetapkan sebagai Lahan Pertanian Pangan Berkelanjutan dapat dilihat dalam tabel 3.

Sinyal positif semacam ini harus dapat ditangkap dengan baik oleh aparat Pemerintah Kabupaten Bantul. Selain itu, Pemerintah Kabupaten Bantul juga harus memperhatikan potensi maupun resistensi yang muncul dari petani pemilik lahan ini. Kebijakan yang digunakan untuk menghimpun kesediaan petani harus tepat sasaran, artinya benarbenar sesuai dengan pola berpikir petani melalui identifikasi terhadap kebutuhan petani dalam pengelolaan lahan maupun pemenuhan 
Tabel 3

Pendapat Petani Pemilik Lahan Mengenai Kesediaan untuk Ditetapkan Sebagai Lahan Pertanian Pangan Berkelanjutan

\begin{tabular}{|c|c|c|c|c|}
\hline No. & Informan & Lokasi & Kesediaan & Keterangan Lain \\
\hline 1 & Nardi & $\begin{array}{l}\text { Keputren, Pleret, } \\
\text { Pleret }\end{array}$ & $\begin{array}{l}\text { Bersedia, akan dialihkan } \\
\text { sedikit untuk dibangun } \\
\text { rumah tinggal. }\end{array}$ & $\begin{array}{l}\text { Luas } \pm 1.000 \mathrm{~m}^{2} \text {, anggota Kelompok Tani Sriti, tidak } \\
\text { pernah menerima bantuan }\end{array}$ \\
\hline 2 & Jamrani & $\begin{array}{l}\text { Kloron, Segoroyoso, } \\
\text { Pleret }\end{array}$ & Bersedia & $\begin{array}{l}\text { Luas } \pm 3.000 \mathrm{~m}^{2} \text {, anggota Kelompok Tani Tirtoyoso I, } \\
\text { tidak pernah menerima bantuan. }\end{array}$ \\
\hline 3 & Ismadi & Kedaton, Pleret, Pleret & Bersedia & $\begin{array}{l}\text { Luas } \pm 1.000 \mathrm{~m}^{2} \text {, anggota Kelompok Tani Tri Tunggal, } \\
\text { lahan berstatus Sertipikat Tanah Petani, menerima bantuan } \\
\text { benih dan pupuk. }\end{array}$ \\
\hline 4 & Suharti & $\begin{array}{l}\text { Kowen, Timbulharjo, } \\
\text { Sewon }\end{array}$ & Bersedia & $\begin{array}{l}\text { Luas } \pm 2.000 \mathrm{~m}^{2} \text {, bukan anggota kelompok tani, belum } \\
\text { pernah menerima bantuan. }\end{array}$ \\
\hline 5 & Sumardi & $\begin{array}{l}\text { Grojogan, Tamanan, } \\
\text { Banguntapan }\end{array}$ & Bersedia & $\begin{array}{l}\text { Luas } \pm 2.000 \mathrm{~m}^{2} \text {, anggota Kelompok Tani Grojogan, } \\
\text { menerima bantuan benih dan pupuk. }\end{array}$ \\
\hline 6 & Sumilan & $\begin{array}{l}\text { Grojogan, Tamanan, } \\
\text { Banguntapan }\end{array}$ & Bersedia & $\begin{array}{l}\text { Luas } \pm 2.000 \mathrm{~m}^{2} \text {, anggota Kelompok Tani Grojogan, saat } \\
\text { ini menjadi lahan tidur. }\end{array}$ \\
\hline 7 & Kadiso & $\begin{array}{l}\text { Samiran, Parangtritis, } \\
\text { Kretek }\end{array}$ & Bersedia & $\begin{array}{l}\text { Luas } \pm 1.000 \mathrm{~m}^{2} \text {, Ketua Kelompok Tani Ngudi Makmur, } \\
\text { menerima bantuan benih, pupuk, gerobak angkut, terpal, } \\
\text { gudang benih, dan peralatan tani. }\end{array}$ \\
\hline 8 & Sumarjan & $\begin{array}{l}\text { Kepuhan, Argorejo, } \\
\text { Sedayu }\end{array}$ & Bersedia & Alih fungsi lahan untuk pembangunan gudang pertanian \\
\hline
\end{tabular}

Sumber: Hasil wawancara dengan informan, 2015 (data diolah)

kebutuhan hidup sehari-hari. Harapannya, kebijakan tersebut nantinya memiliki daya tarik bagi petani hingga akhirnya bersedia untuk ditetapkan sebagai Lahan Pertanian Pangan Berkelanjutan.

Keenam, terbatasnya ketersediaan lahan pertanian. Keterbatasan lahan pertanian salah satunya disebabkan oleh belum adanya sinkronisasi data lahan pertanian antar instansi di lingkup Pemerintah Kabupaten Bantul yang mengakibatkan tidak akuratnya data yang akan menjadi dasar penyusunan kebijakan Perlindungan Lahan Pertanian Pangan Berkelanjutan dan target keluasan Lahan Pertanian Pangan Berkelanjutan belum tentu dapat terpenuhi sebagaimana ketentuan dalam Perda Provinsi DIY Nomor 10 Tahun 2011. Saat ini, berbagai upaya pemetaan lahan pertanian telah selesai dilakukan dan dapat diketahui keluasan lahan pertanian yang ada. Namun, berbagai upaya inventarisasi lahan pertanian tersebut menghasilkan keluasan yang tidak sama karena diselenggarakan oleh pihak yang berbeda-beda.

Sebagai contoh, inventarisasi yang dilakukan oleh Bappeda Kabupaten Bantul melalui pihak ketiga menghasilkan keluasan lahan pertanian \pm 15.000 hektar. Sementara, hasil inventarisasi yang dilakukan oleh Kantor Pertanahan Kabupaten Bantul seluas \pm 16.000 hektar. Data keluasan lahan yang dihimpun Kantor Pertanahan ini hanya mengindikasikan keluasan lahan pertanian secara legal formal saja. Artinya, dapat terjadi keluasan lahan pertanian yang sesungguhnya lebih besar atau lebih kecil dari data yang dirilis. Hal ini terjadi akibat adanya perbedaan antara kondisi eksisting di lapangan dengan data legal formal yang ada. Sering ditemui lahan pertanian yang telah beralih fungsi, namun belum memenuhi prosedur perijinan alih fungsi sebagaimana ketentuan yang berlaku. Sebaliknya, secara legal formal ijin alih fungsi atas suatu lahan pertanian telah 
Gesthi Ika Janti, Edhi Martono, dan Subejo -- Perlindungan Lahan Pertanian Pangan Berkelanjutan Guna Memperkokoh Ketahanan Pangan Wilayah (Studi Di Kabupaten Bantul, Daerah Istimewa Yogyakarta)

diterbitkan namun eksisting di lapangan menunjukkan lahan tersebut masih digunakan sebagai lahan pertanian.

\section{Strategi Mewujudkan Perlindungan Lahan Pertanian Pangan Berkelanjutan Untuk Memperkokoh Ketahanan Pangan Wilayah Kabupaten Bantul}

\section{Strategi mewujudkan Perlindungan Lahan Pertanian Pangan Berkelanjutan}

Berdasarkan kendala-kendala yang ditemui dalam perencanaan dan penyusunan kebijakan Perlindungan Lahan Pertanian Pangan Berkelanjutan, guna memperkokoh ketahanan pangan di Kabupaten Bantul dirumuskan strategi sebagai berikut.

Pertama, review kebijakan penataan ruang di Kabupaten Bantul. Usulan agar segera dilakukan review terhadap kebijakan penataan ruang di Kabupaten Bantul ini sangat mendesak untuk segera dilakukan, mengingat pemanfaatan ruang yang ada selama ini belum cukup mengakomodasi sektor pertanian. Penetapan Kawasan Perkotaan Yogyakarta pada Kecamatan Banguntapan, Kecamatan Sewon, dan Kecamatan Kasihan justru membuka peluang yang sangat besar bagi alih fungsi lahan pertanian secara masif, mengingat tiga kawasan tersebut seluruhnya merupakan blok kuning. Hal ini dapat diartikan bahwa meskipun saat ini masih terdapat lahan pertanian pada tiga kecamatan tersebut, namun dalam jangka panjang keberadaannya belum tentu dapat dipertahankan karena belum ada payung hukum yang dapat melindungi eksisting lahan pertanian pada kawasan tersebut. Oleh karena itu, harus dilakukan review terhadap RTRW dan RDTR Kecamatan untuk mengubah peruntukan kawasan tersebut dari seluruhnya blok kuning menjadi blok hijau pada lahan-lahan pertanian yang masih dapat dipertahankan keberadaannya.

Pengaturan ini menjadi penting karena Pemerintah Kabupaten Bantul harus dapat memenuhi ketentuan Perda Provinsi DIY Nomor 10Tahun 2011 yang mengatur mengenai Lahan Pertanian Pangan Berkelanjutan di Kabupaten Bantul seluas 13.000 hektar. Di samping itu, melalui review ini diharapkan laju alih fungsi lahan pertanian dapat dikendalikan dan pengembangan kawasan perumahan dan permukiman dapat diarahkan pada kawasan yang telah ditentukan. Terhadap lahan-lahan sawah yang masih dikelola dipertahankan fungsinya sebagai lahan pertanian untuk kemudian ditetapkan menjadi Lahan Pertanian Pangan Berkelanjutan.

Upaya peninjauan kembali ini belum berjalan secara optimal karena adanya perbedaan rumusan kebijakan penataan ruang antara Pemerintah Kabupaten Bantul dan Pemerintah Daerah DIY, khususnya pada Kawasan Perkotaan Yogyakarta. Pada RDTR Kecamatan Banguntapan, Pemerintah Kabupaten Bantul menginginkan seluruhnya dilepaskan menjadi kawasan perkotaan (permukiman) dengan kepadatan tinggi. Di lain pihak, Pemerintah Daerah DIY menginginkan agar Kecamatan Banguntapan tidak seluruhnya ditetapkan sebagai blok kuning, tetapi juga mengalokasikan 30\% dari total keluasan lahan di kecamatan ini sebagai green belt. Green belt ini menjadi sabuk hijau dan ruang terbuka hijau bagi Kawasan Perkotaan Yogyakarta, sehingga lokasinya harus sudah ditentukan dalam RDTR Kecamatan.

Selain melakukan review, Pemerintah Kabupaten Bantul juga harus dan mendorong selesainya penyusunan regulasi yang mewadahi Kawasan Perkotaan Yogyakarta 
karena hingga saat ini belum ada regulasi formal yang mengatur mengenai Rencana Tata Ruang Kawasan Perkotaan Yogyakarta secara spesifik. Terlepas dari konsep dan implementasi Kawasan Perkotaan Yogyakarta di Kabupaten Bantul, regulasi untuk mewadahi penetapan dan pengaturan Kawasan Perkotaan Yogyakarta ini sangat penting untuk direalisasikan dalam bentuk Rencana Tata Ruang Kawasan Perkotaan Yogyakarta guna mewujudkan keterpaduan penyelenggaraan penataan ruang antara wilayah Kabupaten Bantul yang tercakup dalam Kawasan Perkotaan Yogyakarta.

Kedua, penegakkan hukum terhadap regulasi penataan ruang di Kabupaten Bantul. Selain review terhadap kebijakan penataan ruang, harus ada upaya tegas untuk mengendalikan alih fungsi lahan, agar lahan hijau yang saat ini masih ada dapat dipertahankan, salah satunya dengan meningkatkan pengawasan dan pengendalian terhadap implementasi kebijakan. Ketentuan mengenai sanksi atas pelanggaran yang terjadi harus diberlakukan secara tegas, baik kepada pengguna lahan (pelaku alih fungsi) maupun kepada aparat pemberi ijin alih fungsi. Sejauh ini, ketentuan pidana yang diatur dalam Perda RTRW belum dilaksanakan sebagaimana ketentuan yang berlaku. Oleh karena itu, tidak salah apabila ketentuan tersebut dipandang hanya sebatas ketentuan wajib di atas kertas saja tanpa memiliki kekuatan hukum bagi setiap pelanggaran yang terjadi.

Kesadaran dan ketaatan hukum serta penegakkan hukum secara adil menjadi syarat utama keberhasilan implementasi regulasi penataan ruang ini. Komitmen dari kepala daerah dan pejabat birokrasi menjadi muara dalam penegakkan hukum terhadap pelanggaran penataan ruang suatu wilayah. Hanya saja komitmen ini masih belum dapat diwujudkan oleh segenap jajaran Pemerintah Kabupaten Bantul.

Ketiga, dukungan pengalokasian anggaran. Harus ada dukungan pengalokasian anggaran perencanaan regulasi Perlindungan Lahan Pertanian Berkelanjutan, baik dari pemerintah pusat maupun pemerintah daerah yang disertai dengan komitmen Pemerintah Kabupaten Bantul untuk meningkatkan proporsi anggaran untuk pembangunan sektor pertanian secara menyeluruh. Sejauh ini, strategi ini belum dilaksanakan karena keterbatasan komunikasi Pemerintah Kabupaten Bantul dengan pemerintah pusat maupun pemerintah daerah. Meskipun Pemerintah Daerah DIY telah mengetahui adanya permasalahan alokasi anggaran ini, namun masih belum memberikan kontribusi karena Pemerintah Kabupaten Bantul dinilai belum memiliki komitmen yang kuat terhadap pengalokasian anggaran.

Keempat, penetapan kawasan perlindungan lahan pertanian pangan berkelanjutan. Guna mengisi kekosongan hukum selama Perda Perlindungan Lahan Pertanian Pangan Berkelanjutan belum dapat ditetapkan, Pemerintah Kabupaten Bantul dapat menetapkan Kawasan Pertanian Pangan Berkelanjutan melalui Peraturan Bupati untuk menekan upaya interest groups mengalihfungsikan lahan pertanian menjadi peruntukan lain yang dinilai lebih menguntungkan secara komersial. Kawasan ini diperoleh berdasarkan pada ketersediaan lahan secara normatif yang ada dan dapat dimanfaatkan sebagai lahan pertanian di Kabupaten Bantul serta lahan pertanian sawah yang masuk dalam Daerah Irigasi (DI) dari 
Gesthi Ika Janti, Edhi Martono, dan Subejo -- Perlindungan Lahan Pertanian Pangan Berkelanjutan Guna Memperkokoh Ketahanan Pangan Wilayah (Studi Di Kabupaten Bantul, Daerah Istimewa Yogyakarta)

Dinas Sumber Daya Air dan Dinas Pekerjaan Umum. Lahan Inti merupakan sawah irigasi yang termasuk kawasan peruntukan pertanian lahan basah irigasi, sedangkan Lahan Penyangga merupakan sawah irigasi yang masuk kawasan dengan peruntukan pertanian lahan kering dan lahan pertanian non irigasi. Luas Lahan Inti yang akan ditetapkan seluas 8.803,52 hektar dan Lahan Penyangga seluas 2.102,43 hektar, sehingga diperoleh keluasan total 10.905,98 hektar.

Gambar 1 menunjukkan Peta Rencana Kawasan Lahan Pertanian Pangan Berkelanjutan Kabupaten Bantul.

Peraturan Bupati ini hanya bersifat pengaturan sementara, maka upaya penyusunan Perda Perlindungan Lahan Pertanian Pangan Berkelanjutan beserta sebaran Lahan Inti maupun Lahan Penyangga/Cadangan harus tetap dilanjutkan. Apabila perda dimaksud telah dapat ditetapkan, selanjutnya Peraturan Bupati harus dicabut agar tidak saling tumpang tindih.

Kelima, penyusunan regulasi pemberian insentif bagi Lahan Pertanian Pangan Berkelanjutan. Pemberian insentif, disinsentif maupun kompensasi sudah diatur dalam Undang-Undang Nomor 41 Tahun 2009 maupun Perda Provinsi DIY Nomor 10 Tahun 2011. Pemerintah Kabupaten Bantul sendiri belum mengatur mengenai pemberian insentif, disinsentif maupun kompensasi karena Perda Perlindungan Lahan Pertanian Pangan Berkelanjutan belum dapat ditetapkan, sedangkan pengaturan Kawasan Lahan Pertanian Pangan Berkelanjutan melalui

Gambar 1

Peta Rencana Kawasan Lahan Pertanian Pangan Berkelanjutan Kabupaten Bantul
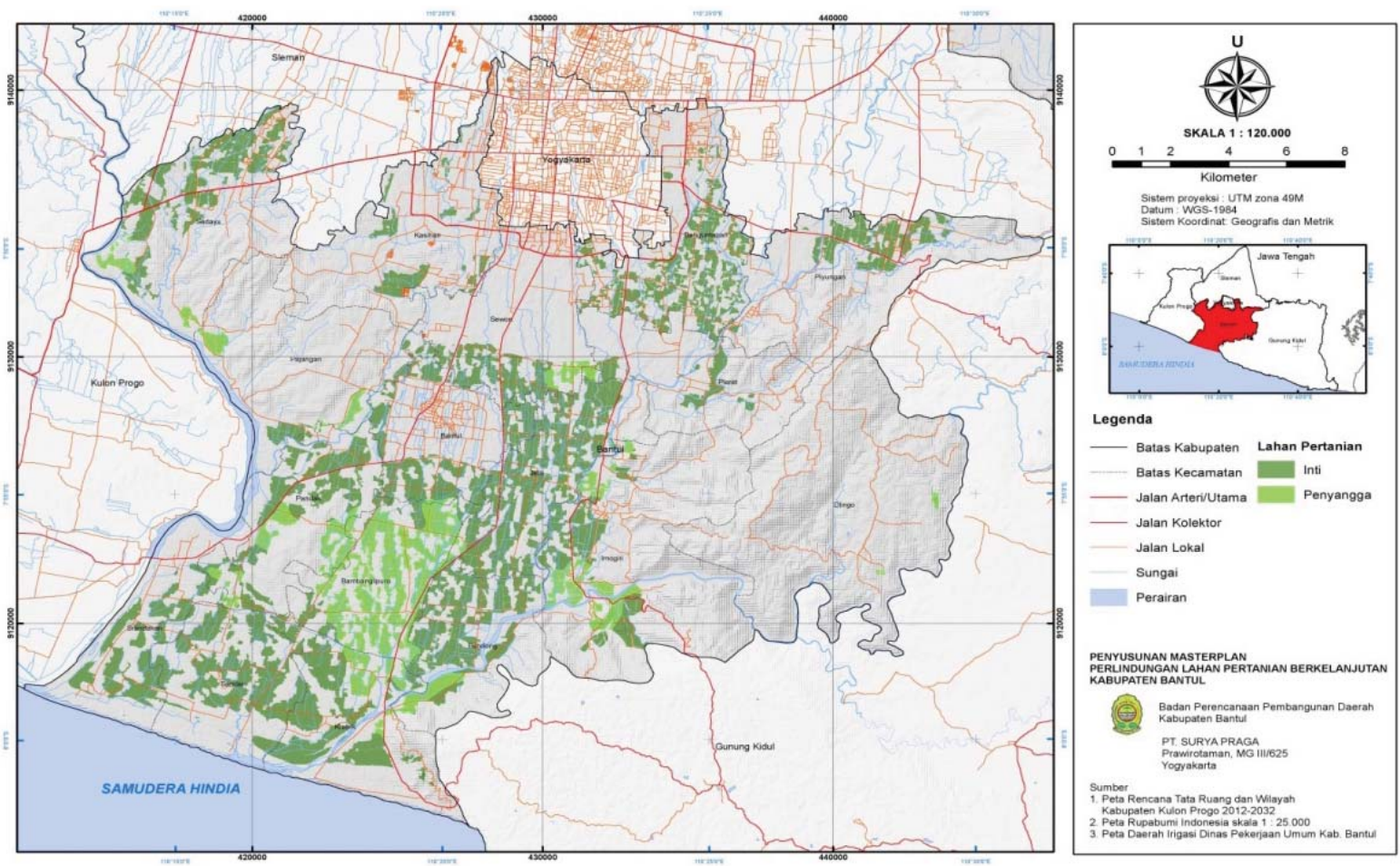

(Sumber: Bappeda Kabupaten Bantul, 2014, dengan penyesuaian peneliti) 
Peraturan Bupati tidak pula mengatur mengenai hal ini.

Pemberian insentif merupakan salah satu instrumen yang digunakan untuk melakukan pengendalian alih fungsi terhadap Lahan Pertanian Pangan Berkelanjutan. Oleh karena itu, Pemerintah Kabupaten Bantul perlu segera menyelesaikan rumusan pemberian insentif bagi Lahan Pertanian Pangan Berkelanjutan untuk menghimpun kesediaan petani dengan mempertimbangkan jenis lahan, kesuburan tanah, luas lahan, irigasi, tingkat fragmentasi lahan, produktivitas usaha tani, lokasi, kolektivitas usaha pertanian, dan/atau praktik usaha tani ramah lingkungan.

Insentif diberikan kepada pemilik lahan, petani penggarap, dan/atau kelompok tani. Insentif yang diberikan dapat berupa insentif biaya produksi, insentif gagal panen/puso, insentif jaminan harga bila terjadi kerugian saat panen raya, insentif pembelian lahan oleh pemerintah, insentif bebas Pajak Bumi dan Bangunan, insentif pemberian beasiswa bagi keluarga petani berprestasi. Selain itu, beberapa bentuk insentif lainnya juga dapat menjadi pertimbangan, yaitu insentif pembiayaan berupa pemberian kredit dan insentif konsolidasi lahan pertanian. Sebagai catatan penting, insentif Lahan Pertanian Pangan Berkelanjutan tidak hanya berasal dari instansi teknis di bidang pertanian saja, tetapi harus ada dukungan dari pihak yang lain di luar bidang pertanian karena kepentingan ketahanan pangan wilayah bersifat lintas sektoral yang melibatkan multi stakeholders.

Keenam, pengembangan lahan pertanian pangan. Untuk mengatasi masalah keterbatasan lahan pertanian yang akan ditetapkan sebagai Lahan Pertanian Pangan Berkelanjutan, dilakukan kegiatan Optimasi Lahan, Sertipikat
Tanah Petani, dan sinkronisasi data lahan pertanian. Kegiatan Optimasi Lahan bertujuan untuk meningkatkan kesuburan dan produktivitas lahan pertanian, melalui pengembangan jaringan irigasi, pemberian pupuk organik, dan pengembangan System of Rice Intensification (SRI). Kegiatan Sertipikat Tanah Petani dilakukan untuk mengendalikan alih fungsi lahan, sedangkan sinkronisasi data lahan pertanian dilakukan bersama-sama antara instansi terkait untuk mewujudkan database lahan pertanian yang valid sebagai referensi pengambilan kebijakan. Baik pengembangan SRI maupun kegiatan Sertipikat Tanah Petani sudah dilaksanakan secara rutin di beberapa wilayah di Kabupaten Bantul, selanjutnya perlu dipertahankan konsistensi pelaksanaannya.

Strategi-strategi tersebut belum seluruhnya dilaksanakan secara maksimal oleh Pemerintah Kabupaten Bantul. Keberhasilan dan konsistensi pelaksanaan hanya terdapat pada upaya pengembangan lahan pertanian pangan melalui pengembangan System of Rice Intensification (SRI), pelaksanaan kegiatan Sertipikat Tanah Petani dan optimasi lahan. Kegiatan-kegiatan tersebut telah memberikan kontribusi bagi penciptaan lahan pertanian potensial maupun pengembangan lahan pertanian yang sudah ada. Apabila dianalisis lebih jauh, keberhasilan pelaksanaan kegiatan tersebut tidak dapat dilepaskan dari peran Kantor Pertanahan Kabupaten Bantul, Dinas Pertanian dan Kehutanan Kabupaten Bantul serta keberadaan Kelompok Tani maupun Gabungan Kelompok Tani di wilayah Kabupaten Bantul.

\section{Status Ketahanan Pangan Wilayah Kabupaten Bantul}

Kondisi ketahanan pangan wilayah di Kabupaten Bantul dianalisis berdasar aspek 
ketersediaan pangan secara makro dengan menggunakan pendekatan produksi tanaman pangan yang dihasilkan dalam kurun waktu tertentu. Komoditas yang digunakan sebagai salah satu tolok ukur adalah beras. Suatu daerah dikategorikan bagus apabila rasio produksi beras per kapita di atas 0,13 ton beras/ jiwa/tahun, asumsinya nilai konsumsi rata-rata sebesar $130 \mathrm{~kg} / \mathrm{kapita} / \mathrm{tahun}$ (Subejo, 2014 : 8). Pada level kabupaten rasio produksi beras per kapita Kabupaten Bantul menunjukkan kondisi ketahanan pangan wilayah pada kategori sedang, yaitu sebesar 0,14 ton beras/ jiwa/tahun. Tabel 4 menunjukkan sebaran status ketahanan pangan wilayah di Kabupaten Bantul berdasarkan rasio produksi beras per kapita.

Dari tabel 4 diketahui bahwa Kecamatan Banguntapan, Kecamatan Kasihan, dan
Kecamatan Pajangan memiliki status ketahanan pangan yang rendah. Hal ini dipengaruhi oleh penetapan KPY pada Kecamatan Banguntapan dan Kecamatan Kasihan dimana jumlah penduduknya semakin meningkat tanpa disertai pertumbuhan lahan pertanian produktif baru. Sementara itu, untuk Kecamatan Pajangan jenis tanah terdiri dari Lithosol dan Grumosol yang berasal dari batuan induk kapur. Kecamatan Pajangan juga memiliki kepadatan penduduk agraris yang paling rendah karena luas lahan sawahnya termasuk yang paling kecil dibandingkan kecamatan lainnya di Kabupaten Bantul.

Sementara itu, Kecamatan Sanden, Kecamatan Kretek, dan Kecamatan Bambanglipuro merupakan kecamatan dengan rasio produksi beras per kapita tertinggi di

Tabel 4

Produksi Beras dan Rasio Beras/Penduduk per Kecamatan di Kabupaten Bantul Tahun 2010

\begin{tabular}{lrrrccc}
\hline \multicolumn{1}{c}{ Kecamatan } & $\begin{array}{c}\text { Jumlah } \\
\text { Penduduk } \\
\text { (Jiwa) }\end{array}$ & $\begin{array}{c}\text { Produksi } \\
\text { Padi (Ton) }\end{array}$ & $\begin{array}{c}\text { Produksi } \\
\text { Beras (Ton) }\end{array}$ & $\begin{array}{c}\text { Rasio Prod. Padi } \\
\text { per Penduduk } \\
\text { (Ton/Jiwa/Tahun) }\end{array}$ & $\begin{array}{c}\text { Rasio Prod. Beras } \\
\text { per Penduduk } \\
\text { (Ton/Jiwa/Tahun) }\end{array}$ & $\begin{array}{c}\text { Status } \\
\text { Ketahanan } \\
\text { Pangan*) }\end{array}$ \\
\hline Srandakan & 28.935 & $5.164,68$ & $3.615,276$ & 0,18 & 0,12 & Sedang \\
Sanden & 29.939 & $12.142,25$ & $8.499,575$ & 0,41 & 0,28 & Tinggi \\
Kretek & 29.829 & $11.447,74$ & $8.013,418$ & 0,38 & 0,27 & Tinggi \\
Pundong & 32.097 & $9.763,21$ & $6.834,247$ & 0,30 & 0,21 & Tinggi \\
Bambanglipuro & 37.921 & $13.574,02$ & $9.501,814$ & 0,36 & 0,25 & Tinggi \\
Pandak & 48.558 & $14.788,20$ & $10.351,740$ & 0,30 & 0,21 & Tinggi \\
Pajangan & 34.467 & $2.218,07$ & $1.552,649$ & 0,06 & 0,05 & Rendah \\
Bantul & 61.344 & $14.866,62$ & $10.406,634$ & 0,24 & 0,17 & Tinggi \\
Jetis & 53.592 & $15.634,70$ & $10.944,290$ & 0,29 & 0,20 & Tinggi \\
Imogiri & 57.534 & $11.827,37$ & $8.279,159$ & 0,21 & 0,14 & Sedang \\
Dlingo & 36.165 & $5.890,98$ & $4.123,686$ & 0,16 & 0,11 & Sedang \\
Pleret & 45.316 & $6.785,48$ & $4.749,830$ & 0,15 & 0,10 & Sedang \\
Piyungan & 52.156 & $13.584,04$ & $9.508,828$ & 0,26 & 0,18 & Tinggi \\
Banguntapan & 131.584 & $14.674,04$ & $10.271,828$ & 0,11 & 0,08 & Rendah \\
Sewon & 110.355 & $16.094,22$ & $11.265,954$ & 0,15 & 0,10 & Sedang \\
Kasihan & 119.271 & $9.236,43$ & $6.465,501$ & 0,08 & 0,05 & Rendah \\
Sedayu & 45.952 & $12.191,57$ & $8.534,099$ & 0,27 & 0,19 & Tinggi \\
\hline Jumlah/rerata & $\mathbf{9 5 5 . 0 1 5}$ & $\mathbf{1 8 9 . 8 8 3 , 6 2}$ & $\mathbf{1 3 2 . 9 1 8 , 5 2 8}$ & $\mathbf{0 , 2 0}$ & $\mathbf{0 , 1 4}$ & Sedang \\
\hline
\end{tabular}

Sumber : BPS dan Dinas Pertanian dan Kehutanan Kabupaten Bantul, 2011 (data diolah)

*) Ekuivalensi produksi beras $=70 \%$ produksi padi.

*) Status ketahanan pangan berdasarkan rasio produksi beras per kapita : Rendah $(<0,10)$, Sedang $(0,10$ -

0,15), Tinggi $(>0,15)$ 
Kabupaten Bantul. Tingkat kesuburan lahan pada wilayah tersebut berada pada level sedang hingga tinggi, serta dikenal sebagai sentra penghasil padi di Kabupaten Bantul. Hal ini tentu tidak dapat dilepaskan dari tingkat alih fungsi lahan yang cukup rendah bila dibandingkan dengan kecamatan yang ditetapkan sebagai Kawasan Perkotaan Yogyakarta serta lahan pada kecamatan tersebut cocok untuk budidaya pertanian lahan basah. Regulasi penataan ruang wilayah di Kabupaten Bantul juga memiliki andil dalam menjadikan kecamatan-kecamatan tersebut sebagai lumbung beras. Lahan yang terletak di wilayah tengah hingga selatan Kabupaten Bantul memiliki tingkat kesuburan yang baik.

Meskipun tingkat produksi beras Kabupaten Bantul mengindikasikan kondisi ketahanan pangan wilayah yang sedang, namun pada lingkup desa masih terdapat kondisi rawan pangan dan gizi. Kerawanan pangan dapat dilihat dari aspek produksi, aspek konsumsi, dan aspek distribusi. Dari aspek produksi ditunjukkan oleh kemampuan produksi yang tidak seimbang dengan kebutuhan pangan masyarakat. Aspek konsumsi ditunjukkan oleh ketidakmampuan membeli pangan akibat rendahnya daya beli, sedangkan aspek distribusi ditunjukkan oleh ketidakseimbangan pasokan untuk memenuhi permintaan pangan, sehingga terjadi kelangkaan pangan.

Desa yang berada dalam kondisi rawan pangan di Kabupaten Bantul adalah Desa Trimurti Kecamatan Srandakan, Desa Imogiri Kecamatan Imogiri, Desa Jagalan Kecamatan Banguntapan, Desa Guwosari Kecamatan Pajangan, dan Desa Ngestiharjo Kecamatan Kasihan. Sementara itu, desa yang berada dalam kondisi waspada adalah Desa Srihardono Kecamatan Pundong. Kerawanan pangan ini disebabkan oleh produksi padi dan umbi-umbian yang rendah akibat sempitnya lahan pertanian, sementara jumlah penduduk terus bertambah serta tingkat kesuburan tanah yang rendah.

Meskipun demikian, kerawanan pangan tidak hanya disebabkan oleh terbatasnya keluasan lahan pertanian maupun rendahnya hasil produksi tanaman pangan di suatu wilayah, tetapi juga dipengaruhi oleh daya beli masyarakat terhadap kebutuhan pangan. Untuk mengatasi hal tersebut, Pemerintah Kabupaten Bantul melakukan program perbaikan mutu beras dan mendorong petani untuk menjual hasil produksi dalam bentuk beras untuk meningkatkan nilai jual. Selain itu, Pemerintah Kabupaten Bantul juga melaksanakan program Aksi Desa Mandiri Pangan guna mendorong masyarakat untuk mampu mencukupi kebutuhan pangannya.

\section{Manajemen Pengembangan Wilayah Guna Perlindungan Lahan Pertanian Pangan Berkelanjutan}

Fakta bahwa alih fungsi lahan pertanian menjadi lahan non pertanian yang semakin meningkat dari tahun ke tahun menunjukkan bahwa alih fungsi lahan pertanian tidak dapat dihilangkan, salah satunya sebagai imbas dari kegiatan pembangunan infrastruktur yang dilakukan. Meskipun regulasi Perlindungan Lahan Pertanian Pangan Berkelanjutan harus segera ditetapkan, kecenderungan alih fungsi tersebut dapat dikendalikan melalui serangkaian kebijakan yang memberikan prioritas pada sektor pertanian sebagai salah satu sektor penting dalam pembangunan. Dalam hal ini, Pemerintah Kabupaten Bantul harus menyusun skema manajemen pengembangan wilayah berdasarkan potensi lahan, biofisik, kecenderungan pembangunan, arahan 
RTRW, aglomerasi perkotaan, ketersediaan akses pelayanan publik, serta kepadatan dan pertumbuhan penduduk pada masing-masing kecamatan. Tujuannya untuk mewujudkan penatagunaan lahan secara optimal, khususnya bagi kepentingan Perlindungan Lahan Pertanian Pangan Berkelanjutan. Gambar 2 menyajikan rekomendasi sebagai alternatif skema perencanaan manajemen pengembangan wilayah yang dapat diusulkan guna Perlindungan Lahan Pertanian Pangan Berkelanjutan.

Dalam penyusunan manajemen pengembangan wilayah Kabupaten Bantul terdapat beberapa aspek yang harus diperhatikan dan dipertimbangkan sebagai berikut:

Pertama, wilayah yang berbatasan langsung dengan Kota Yogyakarta diarahkan sebagai kawasan aglomerasi perkotaan dimana pemanfaatannya diatur untuk pengembangan permukiman, kegiatan pendidikan, perindustrian, dan sebagian dipertahankan sebagai ruang terbuka hijau (green belt area). Wilayah ini meliputi Kecamatan Banguntapan, Kecamatan Sewon, dan Kecamatan Kasihan.

Kedua, wilayah yang berada di tengah diarahkan sebagai pusat pemerintahan (ibukota kabupaten), kawasan perindustrian, perdagangan dan jasa, serta terhadap eksisting lahan pertanian ditetapkan sebagai Lahan Penyangga Lahan Pertanian Pangan Berkelanjutan. Wilayah ini meliputi Kecamatan Bantul, Kecamatan Sewon, Kecamatan Sedayu, Kecamatan Piyungan, Kecamatan Pajangan, dan Kecamatan Dlingo.

Gambar 2

Alternatif Skema Perencanaan Manajemen Pengembangan Wilayah

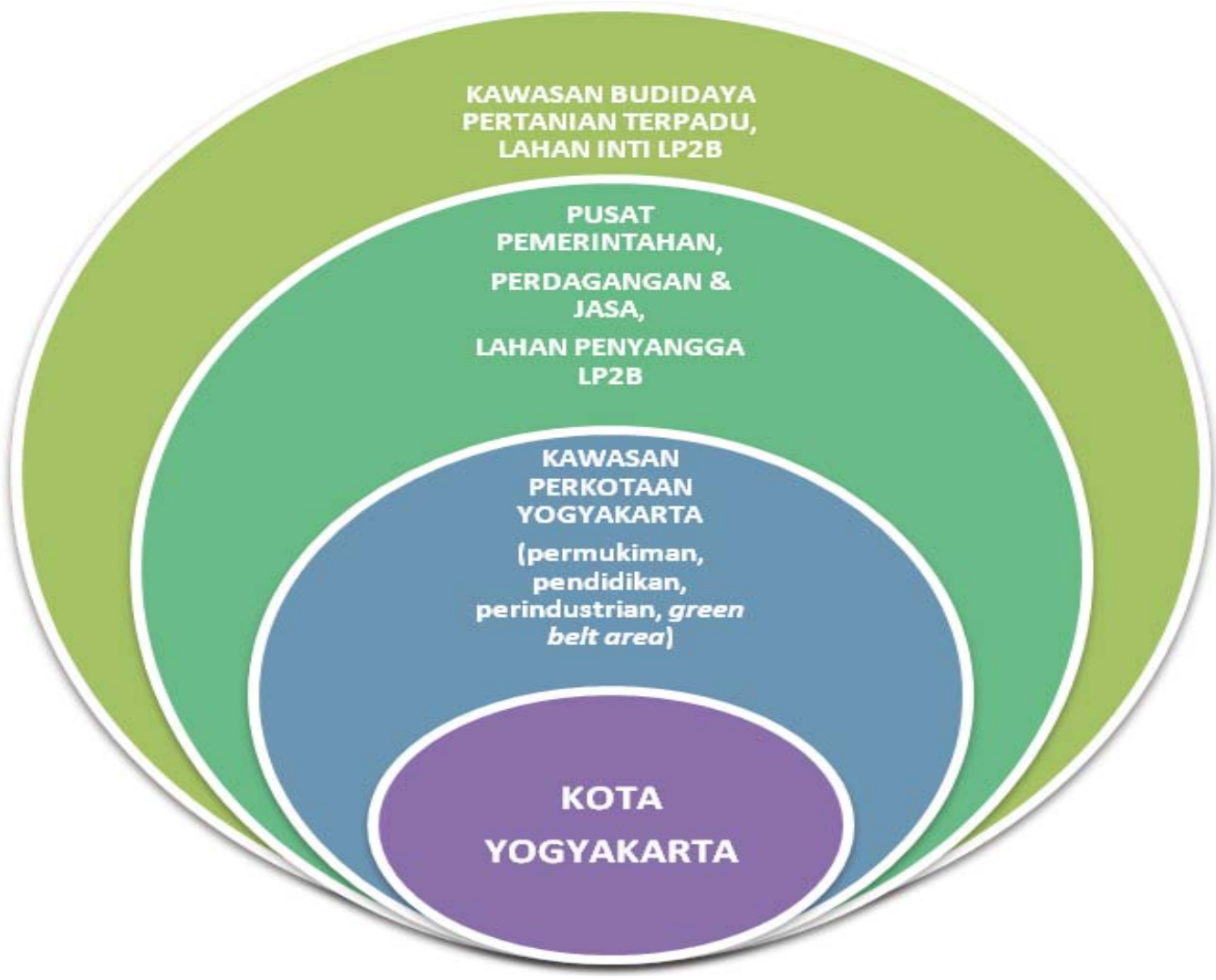

(Sumber : Rekomendasi peneliti) 
Ketiga, wilayah yang akan ditetapkan sebagai kawasan budidaya pertanian terpadu harus memiliki potensi sumber daya yang berupa tanah, ketersediaan air ataupun jaringan irigasi, serta kesesuaian vegetasi. Kriteria ini sesuai dengan tipologi lahan yang terletak di bagian Selatan Kabupaten Bantul, meliputi Kecamatan Pleret, Kecamatan Imogiri, Kecamatan Jetis, Kecamatan Srandakan, Kecamatan Kretek, Kecamatan Bambanglipuro, Kecamatan Pandak, dan Kecamatan Pundong.

Program pembangunan infrastruktur yang dilakukan oleh Pemerintah Kabupaten Bantul juga harus mendukung skema manajemen pengembangan wilayah tersebut. Sebagai contoh, pada wilayah yang ditetapkan sebagai kawasan budidaya pertanian, maka pembangunan infrastrukturnya diprioritaskan pada sektor pertanian. Perbaikan prasarana dan sarana transportasi dilakukan dengan tujuan memberikan kemudahan akses bagi petani dalam mengelola dan mendistribusikan hasil budidaya pertanian. Hal ini tentunya berbeda dengan pembangunan prasarana dan sarana transportasi pada kawasan lain yang diarahkan untuk memberikan kemudahan mobilitas penduduk dalam mengakses pelayanan publik. Dengan demikian, masing-masing peruntukan kawasan dapat berfungsi sebagaimana perencanaannya.

\section{Peran Perlindungan Lahan Pertanian} Pangan Berkelanjutan dalam Memperkokoh Ketahanan Pangan Wilayah

Sejauh ini, perhatian pemerintah terhadap aktivitas alih fungsi lahan masih terfokus pada aspek pengendalian dan dampaknya bagi produksi komoditas pertanian tanaman pangan yang dihasilkan. Sementara itu, aspek sosial ekonomi dari keluarga petani yang mengalihfungsikan lahan pertaniannya belum mendapatkan perhatian yang memadai. Apabila bertolak pada pandangan bahwa tidak mudah bagi petani untuk beralih profesi, maka petani pemilik lahan yang mengalihfungsikan lahan mereka dapat dikategorikan sebagai kelompok rentan.

Oleh karena itu, perlu dilakukan pendampingan agar tetap mampu menghasilkan pendapatan dan meningkatkan kesejahteraan keluarga secara berkelanjutan. Hal ini dilatarbelakangi kekhawatiran akan pemanfaatan uang hasil penjualan lahan yang tidak tepat sasaran. Melalui pendampingan yang dilakukan oleh pemerintah, baik itu melalui penyuluh pertanian maupun instansi terkait lainnya, mereka dapat diarahkan untuk menginvestasikan uang hasil penjualan lahan untuk membeli lahan produktif baru apabila mengalami kesulitan untuk beralih profesi di luar sektor pertanian. Alternatif lainnya, menggunakan uang tersebut sebagai modal usaha dengan pendampingan dari instansi teknis terkait. Apabila lahan pertanian tersebut dijual kepada pengembang, maka pemerintah harus dapat menjembatani agar petani yang semula memiliki lahan dapat menjadi bagian dari pemilik saham. Dengan kata lain, pemerintah harus dapat menyiapkan alternatif mata pencaharian agar kesejahteraan petani dapat terwujud meski telah mengalihfungsikan lahan pertaniannya.

Perda Perlindungan Lahan Pertanian Pangan Berkelanjutan ini nantinya berperan penting dalam upaya mengendalikan kegiatan alih fungsi lahan pertanian pangan, khususnya lahan sawah. Ketahanan pangan, baik wilayah maupun nasional, mensyaratkan adanya ketersediaan lahan yang cukup agar sektor pertanian dapat dikembangkan secara optimal dan menghasilkan produk tanaman pangan 
yang berdaya saing. Dengan demikian, diperlukan suatu regulasi mengenai arah dan kebijakan perlindungan lahan pertanian pangan yang berkelanjutan secara holistik dan terpadu, dengan melibatkan seluruh pihak terkait, baik pemerintah, pemilik modal maupun masyarakat. Adanya pengaturan secara komprehensif dan sistematis dalam wadah regulasi yang sah secara hukum akan mendorong penyelenggaraan pembangunan pertanian pangan berkelanjutan. Muara dari seluruh pengaturan tersebut tidak lain terwujudnya ketahanan pangan wilayah dan peningkatan kesejahteraan petani.

\section{SIMPULAN}

Berdasar uraian di atas dapat ditarik simpulan sebagai berikut.

Pertama, perencanaan kebijakan Perlindungan Lahan Pertanian Pangan Berkelanjutan di Kabupaten Bantul baru sampai pada tahap penyusunan berbagai studi yang diperlukan guna perumusan Naskah Akademis, yaitu Pemetaan Kesuburan Lahan, Neraca Sumber Daya Alam, dan Kajian Lingkungan Hidup Strategis. Kendala dalam perencanaan dan implementasi Perlindungan Lahan Pertanian Pangan Berkelanjutan, yaitu : (1). Kebijakan penataan ruang wilayah yang belum cukup melindungi eksisting lahan pertanian pangan. (2). Pelanggaran regulasi penataan ruang wilayah. (3). Keterbatasan alokasi anggaran perencanaan kebijakan. (4). Pemegang kekuasaan dan pemilik kapital sebagai kelompok yang berkepentingan. (5). Sulit memperoleh kesediaan petani. (6). Terbatasnya ketersediaan lahan pertanian.

Kedua, guna memperkokoh ketahanan pangan wilayah di Kabupaten Bantul dirumuskan strategi sebagai berikut: (1).
Peninjauan kembali terhadap kebijakan penataan ruang wilayah yang berupa review terhadap RDTR Kecamatan yang ditetapkan sebagai Kawasan Perkotaan Yogyakarta dan mendorong selesainya penyusunan regulasi yang mewadahi Kawasan Perkotaan Yogyakarta. (2). Dilakukan penegakkan hukum terhadap regulasi penataan ruang wilayah (3). Dukungan pengalokasian anggaran perencanaan regulasi Perlindungan Lahan Pertanian Berkelanjutan (4). Menetapkan regulasi Perlindungan Lahan Pertanian Pangan Berkelanjutan, baik dalam bentuk Perda maupun Peraturan Bupati (5). Kebijakan pemberian insentif bagi Lahan Pertanian Pangan Berkelanjutan. (6). Kegiatan optimasi lahan untuk meningkatkan kesuburan dan produktivitas lahan pertanian, kegiatan Sertipikat Tanah Petani untuk mengendalikan alih fungsi lahan, dan sinkronisasi data lahan pertanian.

Ketiga, pemerintah Kabupaten Bantul harus segera melaksanakan kegiatan sosialisasi mengenai Perlindungan Lahan Pertanian Pangan Berkelanjutan guna menggalang partisipasi dan kesediaan masyarakat petani. Selain itu, perluasan cakupan wilayah kegiatan Sertipikat Tanah Petani dilakukan meliputi seluruh wilayah administratif Kabupaten Bantul, termasuk pada kecamatan yang ditetapkan sebagai Kawasan Perkotaan Yogyakarta guna mempertahankan eksisting lahan pertanian. Sebagai kompensasi atas penyusutan lahan pertanian yang terjadi pada kecamatan yang ditetapkan sebagai Kawasan Perkotaan Yogyakarta, maka perlu diupayakan pengembangan budidaya pertanian pada lahan-lahan terlantar maupun lahan marjinal di luar kecamatan yang termasuk dalam Kawasan Perkotaan 
Yogyakarta. Lahan tersebut nantinya tidak hanya dipergunakan untuk budidaya padi saja, tetapi dikembangkan dalam rangka pembangunan kawasan budidaya pertanian terpadu sebagai wujud diversifikasi usaha.

Keempat, peningkatan produktivitas pangan utama (padi) menjadi salah satu upaya untuk memperkokoh ketahanan pangan wilayah dengan cara : (1). Peningkatan kesuburan lahan pertanian melalui penggunaan pupuk organik secara tepat. (2). Penciptaan lahan pertanian produktif baru yang potensial, khususnya yang berada di kawasan pesisir Pantai Selatan dan optimalisasi pemanfaatan lahan terlantar dan lahan marjinal guna pengembangan budidaya pertanian secara terpadu. (3). Membangun dan meningkatkan kualitas jaringan irigasi pada seluruh kawasan budidaya pertanian lahan basah menjadi irigasi teknis. (4). Pengembangan pola budidaya SRI secara menyeluruh di wilayah Kabupaten Bantul. (5). Penyediaan dan distribusi bibit unggul pertanian tanaman pangan, (6) peningkatan kualitas tenaga kerja (petani) melalui kegiatan pelatihan maupun pendampingan secara periodik (7). Mengembangkan inovasi maupun perubahan teknologi untuk peningkatan kapasitas produksi dan produktivitas pertanian tanaman pangan.

Kelima, untuk mengatasi lahan pertanian yang semakin sempit dan mengurangi ketergantungan pada komoditas beras sebagai bahan pangan utama, perlu dilakukan diversifikasi pangan lokal melalui budidaya berbagai umbi-umbian maupun buah-buahan dengan mengoptimalkan pemanfaatan lahan pekarangan melalui peran Kelompok Wanita Tani (KWT). Hasil dari budidaya tersebut dapat diolah menjadi alternatif bahan pangan lokal sebagai pengganti beras. Di samping itu, perlu pula didukung dengan upaya diversifikasi lahan pertanian pangan, dengan cara pola tanam, tumpang sari dan/atau sistem pertanian terpadu.

\section{DAFTAR PUSTAKA}

Bakry, Aminuddin, 2010, "Kebijakan Pendidikan Sebagai Kebijakan Publik”, Jurnal MEDTEK, Vol. 2, No. 1, hal. 1-13.

Bappeda Kabupaten Bantul, 2012, Laporan Akhir Pemetaan Kesuburan Lahan Kabupaten Bantul Tahun Anggaran 2012, Bantul : Bappeda Kabupaten Bantul. 2014, Paparan Lahan Pertanian Pangan Berkelanjutan Kabupaten Bantul, Bantul : Bappeda Kabupaten Bantul.

Barlowe, Raleigh, 1978, Land Resource Economics: The Economics of Real Property (second edition), New Jersey : Prentice-Hall, Inc.

BPS Kabupaten Bantul, 2014, Bantul Dalam Angka 2014, Bantul : BPS Kabupaten Bantul.

Dinas Pertanian dan Kehutanan Kabupaten Bantul, 2011, Data Statistik Pertanian Tahun 2010, Bantul : Dinas Pertanian dan Kehutanan Kabupaten Bantul.

Iqbal, Muhammad dan Sumaryanto, 2007, Strategi Pengendalian Alih Fungsi Lahan Pertanian Bertumpu Pada Partisipasi Masyarakat. Jurnal Analisis Kebijakan Pertanian, Volume 5, No. 2, hal. 167-182.

Kantor Pertanahan Kabupaten Bantul, 2014, Laporan Tahunan Tahun 2014, Seksi Pengaturan dan Penataan Pertanahan, Bantul: Kantor Pertanahan Kabupaten Bantul.

Karini, Dyah May, 2013, Dampak Alih Fungsi Lahan Persawahan Terhadap Produksi 
Gesthi Ika Janti, Edhi Martono, dan Subejo -- Perlindungan Lahan Pertanian Pangan Berkelanjutan Guna Memperkokoh Ketahanan Pangan Wilayah (Studi Di Kabupaten Bantul, Daerah Istimewa Yogyakarta)

Beras Dalam Rangka Ketahanan Pangan, Tesis: Universitas Gadjah Mada.

Nurhadi, Sandi, 2010, Strategi Pengembangan Ketahanan Pangan (Studi di Kabupaten Bantul Propinsi Daerah Istimewa Yogyakarta), Tesis: Universitas Gadjah Mada.

Pemerintah Kabupaten Bantul, 2014 Laporan Akuntabilitas Kinerja Instansi Pemerintah (LAKIP) Kabupaten Bantul Tahun 2013, Bantul : Pemerintah Kabupaten Bantul.

Rustiadi, E. dan W. Reti, 2008, Urgensi Lahan Pertanian Pangan Abadi dalam Perspektif Ketahanan Pangan, dalam Arsyad,S dan E. Rustiadi (Ed), Penyelamatan Tanah, Air dan Lingkungan, Jakarta : Crestpent Press dan Yayasan Obor Indonesia.

Rustiadi, E., Saefulhakim, S., dan Panuju, Dyah R., 2011, Perencanaan dan Pengembangan Wilayah, Jakarta : Crestpent Press dan Yayasan Obor Indonesia.

Subejo, 2014, "Beras dan Problematika Pangan Nasional”, dalam Ekonomi Perberasan Indonesia, dalam Krisnamurthi, Bayu (Ed), Bogor : Perhimpunan Ekonomi Pertanian Indonesia (Perhepi).

Wheelan, Charles, 2011, Introduction to Public Policy, New York : W.W. Norton \& Company, Inc.

\section{Peraturan Perundangan}

Undang-Undang Republik Indonesia Nomor 41 Tahun 2009 Tentang Perlindungan Lahan Pertanian Pangan Berkelanjutan.

Peraturan Pemerintah Nomor 15 Tahun 2010 Tentang Penyelenggaraan Penataan Ruang.

Peraturan Daerah Daerah Istimewa Yogyakarta Nomor 10 Tahun 2011 Tentang Perlindungan Lahan Pertanian Pangan Berkelanjutan.

Peraturan Daerah Kabupaten Bantul Nomor 4 Tahun 2011 Tentang Rencana Tata Ruang Wilayah Kabupaten Bantul Tahun 2010 $-2030$.

Peraturan Daerah Kabupaten Bantul Nomor 05 Tahun 2011 Tentang Bangunan Gedung

Peraturan Bupati Bantul Nomor 36 Tahun 2011 Tentang Pedoman Pembangunan Perumahan.

\section{Internet}

Anonim, 2011, 200 Hektar Lahan Pertanian DIY Beralih Fungsi, $<$ si $>$ (diakses 11 Mei 2014).

Anonim, 2013, Alih Fungsi Lahan Pertanian di Indonesia 80 Ribu Hektar per Tahun, <http://www.pikiran-rakyat.com/ node/263653> (diakses 1 Juni 2014). 